\title{
Macbeth - sob a luz desse estranho sol. Shakespeare e Artaud, entre a teatralidade e a performatividade
}

Verônica Fabrini ${ }^{1}$

\section{Resumo}

Este texto apresenta, de forma mais ou menos organizada, um delírio sobre as estratégias de montagem e desmontagem da peça Macbeth por meio de um processo mito-guiado, ou seja, guiado por uma perspectiva hermenêutica, pelos passos alados de Hermes. Essa escrita busca refletir, apoiada na prática criativa, sobre as dissonâncias e consonânias entre teatralidade e performatividade, contraponteando mito, rito e dramaturgia.

Palavras chave: Mito; Imaginário; Cena.

\section{Abstract}

This paper presents a more or less organized thought on strategies for construction and de-construction of Shakespeare's Macbeth through a process of myth-driven, ie, guided by a hermeneutic perspective, or by the steps winged Hermes. This writing seeks a reflexion, supported by creative practice, about the dissonance and consonance between theatricality and performativity, playing myth, rite and dramaturgy.

Keywords: Myth; Imaginary; Scene.

\section{Assim como na Natureza, no Teatro nada se cria, nada se perde, tudo se transforma.}

Três temas intimamente conectados vêm ocupando, já faz um tempo, os estudiosos das artes da cena. Como se ao conceituar ou nomear algo - e aqui me refiro ao trio fantástico teatralidade/performatividade e pós-dramático - esse algo ganhasse autonomia em relação ao solo que o gerou. Aqui, desejo tocar nesses temas de maneira humilde, quero dizer, perto do húmus onde eles brotam. Divaguemos com a imagem do húmus, pois isso já é um procedimento mito-guiado. Ela evoca a materialidade macia da terra, evoca ainda um lugar de origem. Muitos estudiosos da cena já escreveram com aguda lucidez sobre esse tri-tema, e por isso aqui busco desbastá-lo, encontrar uma simplicidade operacional que nos devolva à sala de trabalho. Por isso o desejo de simplificar, ancorar-nos na physis, umidecer o tema para que ele brote em criação.

\footnotetext{
${ }^{1}$ Verônica Fabrini é professora do Departamento de Artes Cênicas da Universidade Estadual de Campinas (UNICAMP)
} 
As reflexões que seguem nasceram de um processo de criação cênico mito-guiado, ou seja, guiado por uma perspectiva hermenêutica simbólica. Numa ação urobórica (a cobra que morde o próprio rabo) convido o "trio de ponta das discussões teatrais" a reencontrar seus pares de origem: o mito e o rito, nos quais teatralidade $\mathrm{e}$ performatividade se friccionam, em que o drama e o além do drama coexistem. Eliminemos o tempo como pede o exercício mítico e habitemos por instantes um illo tempore sem "prés" ou "pós", tempo de pura presença - como na cena. A cena instaura, em sua materialidade no aqui-e-agora, o mito. É o lugar das aparições, dos fantasmas. Dois planos coabitam o mesmo espaço-tempo: imanência e transcendência. No espaço concreto da cena, o atuante se dá a ver, afirma sua presença, seduz o olhar do espectador, da testemunhada ação, instiga o olhar do outro a destacá-lo da realidade. Mas, ao mesmo tempo, dela se alimenta. O espectador, por sua vez, está no lugar-de-onde-se-vê. Excitação da imaginação. Daí a tentação da efabulação, o desejo de ficcionalizar. J. Ferál é clara quando afirma que a teatralidade nasce do olhar do observador, desse emolduramento por um olhar encantado.

Em tempo: essas reflexões nasceram na sala de aula, são frutos de um processo pedagógico no campo da prática. Racionalizações são necessárias, alimentam a cena, mas não a "resolvem", pois a cena deve falar por ela mesma. Uma cena é uma evidência e não uma explicação. Busco uma analogia simples, concreta e física para experimentar esses dois conceitos, essenciais para a compreensão da cena e para a criação cênica. Ladies first! Inicio com Lou Salomé (1991) e sua contundente relação entre arte e eroticidade, entre eroticidade e criação. No amor erótico a conexão psicofísica é uma evidência. Buscando a experiência do conceito, seria então um enamoramento, uma resposta ao encanto atiçado pelo outro. É o olhar de fora que teatraliza. No meio do caos do cotidiano, "o outro" se destaca. Ao seu redor, pela ação do meu olhar, gera-se uma bolha no espaço-tempo na qual tudo se suspende e ganha outra qualidade, imanta-se de graça. E eu suspiro. Contemplo. Aqui teatralidade emana do próprio nome "teatro" em sua conhecida origem grega: "lugar de onde se vê".

the spectator's gaze created a spatial cleft from which illusion emerge - illusion whose vehicle the spectator had selected from among events, behaviours, physical bodies, objects and space without regard for the fictional or real nature of the vehicle's origin. Theatricality occurred under two conditions: first, through a performer's reallocation of the quotidian space that he occupies; second, through a spectator's gaze framing a quotidian space that he does not occupy. Such actions create a cleft that divides the space in the 'outside' and the 'inside' of the theatricality. This 
Teatralidade implica no encontro com o outro, alteridade. Esta será sempre um mistério e, como tal, capaz de suscitar no espectador o desejo de imaginar, de inventar, ficcionalizar. Importante dizer que esse "olhar de fora" não é só do espectador. É também do ator em relação à cena na qual ele próprio se insere, ou dele enquanto observador do personagem latente nas linhas escritas pelo dramaturgo. Do ponto de vista da criação cênica, a questão da espacialidade é fundamental para experiência da teatralidade, pois o espaço é a dimensão da atenção diferenciada. Na dimensão espacial diferenciamos eu e você, aqui e ali, dentro e fora.

Já na performatividade, nossa referência é o lado "de dentro". Retomando a metáfora da eroticidade, nossa perspectiva é daquele que se mostra frente ao olhar do outro, daquele que seduz, portanto daquele que age (ou daquele que sabe que age, mesmo não agindo...). Estamos no campo da ação pura, anterior a qualquer construção de sentido. Por devorar qualquer construção de sentido, evoca a imagem de Cronos comendo os próprios filhos; num processo mito-guiado, a dimensão temporal (das mais múltiplas temporalidades) guia o ator na experiência da performatividade. Entre o antes e o depois, a evidência da presença crava-se no tempo. A ação é a senhora do tempo, é fluxo. Voltando à metáfora do sedutor, a performatividade coloca em evidência (anterior a qualquer construção ficcional) o sujeito em seu esplendor e risco, no momento anterior a qualquer linguagem e, portanto, a qualquer significação. Daí sua potência em gerar poéticas, sua potência matricial. A performatividade nos coloca frente ao abismo do "pré.' Antes de tudo, o sedutor seduz porque é um corpo, uma presença, uma presença desejante, que atiça e pede o outro.

O teatro pós-dramático, ao problematizar o teatro contemporâneo, expõe ao sol apolíneo da razão essa constituição dúplice: ação e narração, performatividade e teatralidade, princípios apolíneos e princípios dionisíacos. No entanto, é importante resguardar o desenvolvimento singular tanto da performance quanto do teatro, para não cairmos numa superficialidade da moda, com o risco de misturar superfícies, sem se preocupar em embaraçar as raízes que as sustentam e nutrem de vida.

É na tensão entre o sedutor e o enamorado, entre a imagem como pura presença e os devires da ficção, que se instaura o processo de criação mito-guiado (talvez um primo-irmão do que Ferál chama de teatro performativo). Transpondo os termos para o procedimento cênico, que é o húmus dessa reflexão, poderíamos dizer que 
um processo mito-guiado nasce da evidência do arquétipo enquanto pré-sentido, enquanto força e a iminência do mito que o tece em narrativa. Ele caminha "para trás", para o húmus. É um procedimento pré-dramático.

Mas porque "pré" e não "pós"? Pelo simples (mas não menos importante) fato da minha perspectiva sobre a cena se apoiar na minha própria origem enquanto artista. Óbvio ululante. Minha entrada para o teatro se deu pela via da dança e pela via do circo. Em outras palavras, o corpo em ação e em risco já desejava a cena antes de qualquer ficção. Mas desejava, pressentia e buscava a ficção no limite da ação, dessa pré-linguagem. Isso está registrado no meu corpo e matiza minha visão e minha ação sobre o teatro e, principalmente sobre a dramaturgia. Quando tomo um texto - uma dramaturgia - peço que seu mythos me guie até os arquétipos sobre os quais ela brotou. É o caminho em direção ao húmus, ou a perspectiva da hermenêutica simbólica, lembrando que esta é guiada por Hermes, o mensageiro entre dois mundos, deus com asas nos tornozelos, imagem que sintetiza tanto a concretude da terra quanto a invisibilidade e a leveza do ar. Hérmes leva o húmus para voar.

\section{Os pés alados de Hermes}

Um processo de criação que se deixa guiar pelo mito tem como chave operacional (ou orientação epistemológica) não uma metodologia, mas uma mitodologia, assim como a definiu o discípulo de Bachelard, Gilbert Durand. Partindo de uma antropologia do imaginário, Durand reabilita tanto a dimensão arquetípica quanto a força diretiva dos mitos. Para ele, o imaginário - e tomo essa afirmação para o artista da cena - não é uma abstração e sim um sistema com estruturas e dinâmicas próprias, sendo essas representadas pelos arquétipos e postas em movimento pelo mito. É justamente a ênfase dada à imaginação e sua projeção material e dinâmica que faz de seu pensamento um poderoso aliado do artista cênico. Somos essa somatória de homo faber (pois precisamos lidar com a physis da cena), homo sapiens (pois a cena deve ser tanto sensível quanto inteligível) e homo symbolicus (pois a cena, para nos afetar profundamente, deve reverberar num outro plano). No trajeto entre as forças arquetípicas, a estruturação dinâmica dos mitos, as múltiplas configurações do símbolo, ou as unidades mínimas das metáforas, circulam infindas imagens consteladas pelo inconsciente coletivo, esse imenso e profundo substrato 
comum que nos faz humanos. Como atores ou encenadores, precisamos ter asas nos pés para circular entre o plano das coisas invisíveis e o das coisas visíveis, entre a imaginação e a cena.

Precisamos ritualizar, é da nossa natureza. Aliás, é da Natureza. A própria Natureza ritualiza seus momentos chave, nos quais a perpetuação da vida (da espécie ou do indivíduo) está em jogo. Observamos em inúmeras espécies uma infinidade de comportamentos ritualizados de acasalamento, proteção ou demarcação de território. Neles, o uso do corpo (ou corpos), do tempo e do espaço são extraordinários e dotados de uma beleza própria, um senso de harmonia e inteireza.

Observando com simplicidade esse substrato comum entre ação ritual e ação cênica, podemos, ao menos por alguns momentos, nos desvencilhar do peso de tantas construções culturais acerca dos desdobramentos desse impulso tão básico do ser humano: ritualizar, fazer teatro; dançar ou encenar Macbeth.

\section{... um conto contado por um idiota, cheio de som e fúria ...}

Como os processos mito-guiados costumam andar para trás, em direção à origem, começo pelo quinto ato, antes de nos encontrarmos com as bruxas, essas "três irmãs do tempo". Na verdade, nesse procedimento a dramaturgia é tratada de forma radial e fractal. Um "ser", pois nele a dramaturgia é um ser vivo, uma Esfinge que propõe enigmas. "Radial", porque a dramaturgia não é trabalhada aprisionada num fluxo linear (mesmo que ela possa ser assim disposta no momento final da organização cênica), mas se espalha em raio, irradia. Como o mito, cada pequena parte, cada imagem contém o todo, portanto, fractal. Tomemos como exemplo a imagem da vida, a resposta máxima ao enigma da Esfinge:

\footnotetext{
Life's but a walking shadow; a poor player, That struts and frets his hours upon the stage, And then is heard no more: it is a tale Told by an idiot, full of sound and fury, Signifying nothing. - Macbeth, Ato V,5
}

Há no teatro elisabetano em geral, e em Shakespeare de modo explicito e recorrente, uma relação especular entre teatro e vida. Arte e vida são um duplo, micro e macrocosmo em íntima correspondência. Assim como na alquimia (e na cena), o teatro elisabetano trabalha diretamente sobre a correspondência entre o material (physis) e sua potencia simbólica que emerge do inconsciente coletivo, ou ainda, como professa a alquimia na tábua esmeraldina: "O que está embaixo é como o que está em cima e o 
que está em cima é como o que está embaixo, para realizar os milagres de uma única coisa" Não apenas em Macbeth, pois tal visão alquímica e metafísica é fundadora da própria concepção elisabetana de teatro. Neste fractal do texto é declarada a relação de duplicidade entre o teatro e o mundo, o teatro e a vida, na qual sua efemeridade é como a de "um pobre (ou mau) ator" (a poor player) que se pavoneia e se aflige nas suas horas sobre o palco (That struts and frets his hours upon the stage), e depois não mais é ouvido (And then is heard no more). Não é simples por coincidência que Shakespeare batizou seu teatro de The Globe.

Destacamos também, nesse mesmo fractal, a materialidade, a carnalidade (e, portanto, o aspecto teatral e performativo...) da vida e da cena nos verbos to strut (caminhar de forma orgulhosa, vaidosa, cabeça erguida e peito projetado para frente, como se desejasse impressionar algum observador...) e to fret (afligir-se, num sentido fisico-fisiológico do termo, pois a palavra evoca a imagem de morder, exasperar-se, debater-se). Sublinhamos ainda a imagem do tempo-espaço destacado de his hours upon the stage, e a evocação ao espaço sonoro no contraste entre is heard no more e full of sound and fury, sendo que esta última - fury, fúria - traz consigo a densidade carnal desesperadamente ancorada no tempo, contrastando com a volatilidade sombria da walking shadow. Somam-se às imagens materiais o cuidadoso tratamento sonoro das palavras (por isso as transcrevi no seu original), cujo ritmo, rima e articulação conduzem a respiração a um estado no qual a própria música das palavras condensa seu sentido profundo. Mas para isso, há que estar atento à metafísica da encenação, como faz esse ilustre parceiro das ações mito-guiadas, Antonin Artaud:

(...) se hoje nos mostramos incapazes de dar de Ésquilo, Sófocles, Shakespeare, uma ideia digna deles é porque parece que perdemos o sentido físico de seus teatros. É porque o lado diretamente humano e atuante de uma dicção, de uma gesticulação, de todo ritmo cênico, nos escapa. (...) é através dessa gesticulação precisa que se modifica com as épocas e que se atualiza os sentimentos, que se pode re-encontar a profunda humanidade daqueles teatros. (ARTAUD, 1999)

Artaud é, portanto, nosso daimon no campo da performatividade, ao passo que a dramaturgia de Shakespeare nos guia pelo campo da teatralidade. Temos então o "Homem-Teatro" e o "Globe Theatre". Na dramaturgia de Shakespeare observamos, primeiramente, a ideia de uma mitologia sincrética - como no caso de Hékate em Macbeth - na qual figuras e eventos mitológicos arcaicos estão disponíveis como um léxico de signos cifrados de um sistema metafísico: novamente a dramaturgia como 
enigma. Segundo, e para nós o mais importante, a ideia desse sistema como um Teatro e dessas imagens como significados de um sistema unificado, que em processos mito-guiados constelam-se em arquétipos ou situações arquetípicas. Terceiro, mas não menos importante, a ideia de drama como um ritual de manipulação da alma, daí a ênfase na imaginação como atividade autogeradora da alma, ao mesmo tempo em que é geradora da cena enquanto imaginação objetivada.

Devemos ter sempre em mente quando falamos de teatro elisabetanao - e, portanto, de Shakespeare - que estamos falando de uma concepção de teatro que por definição é inseparável de sua teatralidade, de seu aspecto concreto e convencional (no sentido simbólico da convenção), ou seja, quando trabalhamos com um texto de Shakespeare percebemos que ele só se revela realmente na cena, na ação. Isso se dá porque esta dramaturgia é inseparável da cena. Isto é igualmente válido para Artaud (1999):

A linguagem do Teatro é em suma a linguagem do palco, que é dinâmica e objetiva. Ela participa de tudo aquilo que pode ser posto sobre um palco em matéria de objetos, de formas, de atitudes, de significações. Mas isto, na medida em que todos estes elementos se organizam e, ao se organizarem, se separam do seu sentido direto, visando criar uma verdadeira linguagem baseada no signo em vez de na palavra.

Artaud também compartilha da visão elisabetana (e dos processos mito-guiados) do teatro como um ritual de manipulação da alma, pois para ele "O teatro é antes de tudo ritual mágico, isto é, ligado a forças, baseado em uma religião, crenças efetivas, e cuja eficácia se traduz em gestos" (idem).

Conjuntamente às construções dos anfiteatros gregos, o teatro elisabetano é considerado um dos mais perfeitos na sua relação orgânica com a dramaturgia nele encenada. Espaço e representação formam um todo, um único organismo, um conjunto significante em constante relação de correspondência com o macrocosmo. Aqui, a dramaturgia converte-se em uma verdadeira cosmogonia. Por isso é um prato saboroso para um processo mito-guiado.

O teatro shakespeariano (e por inspiração, assim desejamos um teatro mito-guiado), seja como construção ou como concepção, pertence ao mesmo fenômeno: uma visão de teatro como duplo do mundo, como podemos observar nesta definição de Frances Yates (1978):

O Globe era um teatro mágico, um teatro cósmico, um teatro religioso, um teatro do ator, projetado para dar total suporte às vozes e gestos dos atores enquanto encenavam o drama da vida do Homem dentro do Teatro do Mundo. (...) O Globe foi para Shakespeare o modelo do universo, a 
ideia do macrocosmo, o palco onde o microcosmo representava seus papéis. Todo mundo é um palco. Essas palavras são literalmente a chave para se compreender o Globe e o teatro elisabetano como um todo. (tradução minha)

Tanto para Shakespeare como para Artaud, nos processos mito-guiados o teatro nasce de uma ideia religiosa e metafísica, ou seja, de correspondências e analogias entre macro e microcosmo, no sentido de "uma ação mágica, real, absolutamente efetiva" (ARTAUD,1999). Teatro "mágico" porque fundado na analogia, na troca de significações, essa deliciosa anarquia poética na qual "é tirado das coisas seu sentido direto e Ihes é dado outro", teatro "metafísico" porque fundado em correspondências, no qual a própria materialidade dos signos nos ensina a identidade entre o concreto e o abstrato, entre o sensível e o inteligível, teatro das imagens profundas, pois Hermes, com seus pés alados, na forma de uma sombra errante, desce até o Hades.

\section{A dramaturgia como enigma da Esfinge}

Gilbert Durand destila sua mitodologia do riquíssimo acervo de ideias, imagens e saberes revelados no iniciático Círculo de Eranos (Ascona, Suíça) ao qual pertencia, juntamente com Jung, Bachelard e Henry Corbin, apenas para citar alguns dos mestres. A visão de mundo "durandiana" (que irá implicar numa ética e numa poética como forma de ação sobre a vida) herda da tradição romântica a importância dada à imaginação criadora na qual explorar o imaginário é tomar conhecimento de um domínio absolutamente real, pois a imaginação é a "rainha das faculdades", "a rainha do real," criadora e governante do mundo, como bem dizia Baudelaire. Da teoria junguiana, Durand faz do inconsciente coletivo/imaginário coletivo o terreno fértil de exploração das homologias das imagens, visto ser este o viveiro que alimenta a alma da espécie, abrigando os grandes arquétipos primordiais. De Bachelard, Durand herda o conceito de imaginação material (similar à imaginação objetiva em Jung), ancorando a imaginação nas forças vivas dos elementos, da physis, e, de forma sintética, nos quatro elementos, dos quais o filósofo deriva sua poética singular e alquímica. Cabe ainda sublinhar sua contundência em evidenciar a grande importância da imaginação criadora, da imaginação poética como uma via de conhecimento real, tão real quanto o saber científico. Como Henri Corbin, Durand assume uma perspectiva hierofânica imaginal, na qual o Mundus imaginalis é tão real quanto este, sendo ele próprio um mundo intermediário entre physis e noos, ou seja, a pura materialidade e a pura abstração do pensamento. Apoiando a 
noção de matrizes imaginárias, de uma homologia das imagens, Durand alia-se a Mircea Eliade, adotando a arquetipologia cultural, a partir da observação de que as religiões (no sentido de re-ligare ou re-leggere) constelam-se em torno de conjuntos complexos de imagens simbólicas que nos reenviam ao mito e ao rito. Nesse sentido, os mitos e os ritos revelam um sentido trans-histórico, de modo que, transpostos para o trabalho sobre a dramaturgia, revelam sentidos profundos do texto, como um "superobjetivo" stanislaviskiano em sua faixa mítica de vibração.

Sobre esse húmus consistente, formado por um saber transdisciplinar que envolve a antropologia, a filosofia e a poética, Durand faz da imaginação a estrada por onde transita Hérmes. Mais do que isso, ele nos mostra que o imaginário (que também podemos chamar de inconsciente coletivo, ou ainda, esgarçando ao máximo o conceito, as emanações do mundo em si) implica um pluralismo das imagens, constelado numa estrutura sistêmica do conjunto dessas imagens infinitamente heterogêneas: ícones, metáforas, símbolos, alegorias, sonhos, mitos, delírios... Dentre essas manifestações do imaginário, para o trabalho com a cena, o símbolo ocupa um lugar privilegiado. Ele excede em significação, possuindo pluridimensões, não expressando nunca sua totalidade. O símbolo convida o espectador a tomar parte, pois ele não explica, mas provoca, não resolve a cena, faz com que ela irradie. Ambíguo e obscuro, o símbolo, pode evocar qualquer qualidade, e, sendo dotado de um poder de ressonância, só pode ser apreendido na experiência vivida. É anterior à linguagem, por isso fala ao espectador em uma "outra dimensão".

O processo mito-guiado compartilha com esses estudiosos do imaginário a ideia de que, além de uma visão de mundo, a arte articula valores mitológicos, instalando um universo exemplar (cujo espaço ao mesmo tempo se destaca e vaza para o cotidiano) e que este universo possui leis e organizações igualmente dotadas de carga mítica, daí a imensa responsabilidade ética que os artistas devem assumir.

Voltemos a Macbeth. Antes mesmo de qualquer figura cênica, tem-se a presença de trovões e raios. A voz da Natureza se faz ouvir, antes mesmo de suas porta-vozes, pelas três bruxas (três Moiras, as três faces de Hekate). Com isso não quero dizer que essas indicações devam ser obrigatoriamente transpostas para a cena. Mais importante que isso é tomá-las em consideração, pois fazem parte do enigma. Enquanto rubrica (dado da dramaturgia) é um desafio, uma tentação a ser decifrada, e para o ator ela é circunstância, materialidade, provocação física. Há raios e trovões e três bruxas estão num pântano. Isso é dado concreto no campo das 
imagens, há que se deixar invadir pela carga simbólica e material dessas imagens, mesmo que sua objetivação na cena seja outra. O que quero dizer é que um processo mito-guiado não se dá apenas na superfície, nos dados visíveis do que vemos em cena. Ele nasce das imagens oferecidas concretamente pela dramaturgia e deixa-se invadir por elas; é um processo que se dá no campo do invisível, do campo das atmosferas, do mana.

$\mathrm{Na}$ cena, as bruxas marcam um encontro para "quando estiver vencida e ganha a batalha", no pântano, antes do por do sol, onde se encontrarão com Macberth. Nessa cena curtíssima, tudo é ambiguidade. Temos a dupla imagem de "perdida e ganha a batalha" (pois uma batalha envolve dois lados), o pântano como lugar meio terra, meio água (barro onde se forja um homem?) e "antes do pôr-do-sol", tempo igualmente ambíguo, hora dos umbrais. As bruxas anunciam seu encontro com Macbeth no espaço-tempo do entre, da encruzilhada, definindo no campo das imagens (e dos valores que essas carregam) o espaço-umbral que permite a suspensão de valores.

A cena seguinte se passa num acampamento de soldados e inicia-se com um toque de alarma. Estamos no mundo dos homens: o acampamento, o toque de alarma. Temos então estabelecido o solo mítico para a colocação do enigma: a natureza, enquanto princípio atemporal, transcendental, mítico versus cultura, temporalidade histórica, fato. Então, o enigma é lançado por Duncan: "Quem é esse homem ensanguentado?".

Enigmas colocados pela dramaturgia só podem ser respondidos pela cena, pois ela não é (ao menos não deve ser, nesse tipo de processo) uma resposta racional. É, antes de tudo, evidência material e contundência sensível. A cena é. Como encenar (teatralizar ou performar) a busca de reposta para o enigma, como provocar uma cena que nos coloque em estado de experiência do enigma? "Quem é esse homem ensanguentado?" se transforma então em roteiro cênico a ser testemunhado pelo espectador (elemento fundamental). É o "Lado B" da dramaturgia de Shakespeare, síntese mito-cênica, lado das forças e não das formas, lado das imagens e não da fábula, fluxo de situações arquetípicas e não sucessão linear de cenas. Campo de experiência mito-guiada que pode tanto preceder (como um aquecimento) a montagem do texto tal qual ele se apresenta, quanto servir de campo de experiência para a compreensão sensível do tri-tema teatralidade/performatividade/teatro pós-dramático. Pode ainda configurar-se como um espetáculo em si, pré-dramático, mítico, pré-apocalíptico. A cena transcorre em uma imagem sintética 
como prólogo (O Paraíso Devastado) e quatro movimentos: Sombra, Crime, Culpa e Expiação. Enfim, um roteiro de dispositivos mito-ativados.

\section{"Quem é esse homem ensanguentado?"}

\section{Prólogo/instalação: Paraíso devastado}

Neo-floresta de Birman ou as Árvores secas do Paraíso. Do lado de fora, na área em frente ao portão que dá acesso a sala, mulheres espalhadas pelo espaço, estão segurando um pequeno galhinho seco, com o cuidado de quem segura uma flor delicada. Elas não realizam quase nenhum movimento. Presença dilatada de bruxas ou Ladies, Lilith ou Eva, vez ou outra surpreendida por poucas, curtas e bruscas agitações - frêmitos de fêmea. Imagem da terra devastada pela guerra. Nada frutifica. Pouco a pouco, começamos a ouvir suas vozes no primeiro texto de Lady Macbeth (famoso texto da carta), cada uma no seu tempo, atentas em construir um tecido sonoro em terças, com a voz mais grave entrando primeiro, seguido pelo voz mais aguda. As palavras devem criar um tecido suave, ditas em descompasso, com cortes, repetições, ficando a escolha a cargo de cada atriz.

Quando as atrizes percebem que o tempo-ritmo e a atmosfera da cena vazaram suficientemente para o espectador, abre-se o Portão do Inferno (ou da sala) e as atrizes - sem abandonar o estado alcançado pela concentração no movimento lento e no texto - conduzem o público para dentro. Lasciate ogni speranza voi che entrate.

\section{Primeiro Movimento: Sombra}

O público entra. Os homens, todos de pé, ocupam todo o espaço cênico. Entoam um canto simples de apenas duas notas graves. As mulheres depositam os pequenos galhos em algum lugar, espalham-se pela cena, em igual e digna verticalidade. À esquerda (a la sinistra), vemos um homem sentado de frente a uma mesa, lap top aberto. Vemos seu rosto iluminado pela tela, mas não vemos a imagem que ele contempla. O portão se fecha, pesado, solene. Silêncio. Silêncio. Atores olham a plateia.

Ao microfone, um ator dá indicações de ações simples, que os atores seguem com igual simplicidade, sem "atuar", apenas realizando as simplíssimas ações indicadas (por exemplo: Mulher olha para homem/ homem olha para mulher). A qualquer momento, os atores podem dizer qualquer parte do primeiro ato de Macbeth, com igual simplicidade, sem "atuar." O homem sentado a la sinistra, liga o som com um 
clic. Ouvimos Quando Corpus Morietur (Stabat Matter, Pergolesi). Homem do lap-top inicia seu texto (extraído de Hamlet) e irá repeti-lo em loop, movido por um estado de tristeza que gradualmente se transforma em eroticidade:

Que obra de arte é o homem! Como é nobre na razão! Como é infinito em faculdades! Na forma e no movimento, como é expressivo e admirável! $\mathrm{Na}$ ação, é como um anjo! Em inteligência, é como um Deus! A beleza do mundo! O paradigma dos animais! E, no entanto, para mim, o que é esta quintessência do pó?

Durante o texto, aos poucos, os outros atores se aproximam para olhar a tela do laptop. Olham e choram do modo mais realista possível (se você olhasse com vagar, também choraria). Dois atores, com um grau a mais de teatralidade giram a mesa até que o público possa ver as imagens. São fotografias de homens decapitados. E são muitas. Cruas, violentas, feias. Os atores desfilam as imagens oferecendo-as para os espectadores, deslizando a mesa (ou algo parecido), pelo proscênio. Ainda se ouve Quando Corpus Morietur. O homem permanece sentado, como se a mesa e as imagens ainda estivessem lá.

Ao final da música ele se levanta, vai até o computador e o desliga. Típico som do computador se desligando. Silêncio. Ele, emprestando as palavras de Macbeth ao final do encontro com as bruxas, anuncia: Assim no ar essas formas corpóreas derreteram com o vento. Os outros atores se dividem em dois grupos, como que separados por esse vento, um feminino e outro misto.

O coro feminino trabalha trechos das bruxas e de Lady Macbeth, passeando pelo ato I e II. O coro misto joga com a ação de mascarar-se e desmascarar-se, colocando e tirando uma meia de nylon na cabeça, deformando as feições, dando corpo e dança ao texto $O$ Belo é feio e o feio é belo. Coração falso e rosto lisonjeiro. Não existe arte que ensine a ler no rosto as feições da alma. Um homem, depois outro e outro, destacam-se do coro e jogam com textos de Macbeth, Ato I e II. Por sua vez, as mulheres fazem o mesmo com o texto de Lady Macbeth. Evocam os espíritos da noite. Algumas com texto, outras com ações. Uma delas retoma o pequeno galho-flor e aconselha: Sê a víbora que na inocente flor se esconde. Respondendo ao anúncio, saem das trevas mulher-Hékate, trazendo dois homens-cães, ferozes, sobre suas quatro patas. Cães que guardam a porta do inferno. Outro Homem, ao microfone, como se apresentasse a humanidade a ela própria, joga com o texto de Macbeth sobre os cães e homens (Ato III,1). 
Quatro atores sacam seus punhais. Inicia-se um jogo de surpreender e ser surpreendido. Trair e ser traído. Os outros atores assumem atitude similar, mas apenas com o olhar, estabelecendo uma atmosfera de desconfiança. Raiva e medo. Focos precisos e focos múltiplos. Duas atrizes jogam com o texto de Lady Macduff $O$ que é um traidor?, ou "a sabedoria da inocência" (Ato IV, 2). Encerra-se a cena e ratifica-se a vitória da sombra, um gesto preciso e forte: Macbeth assassinou o sono, e Cawdor não dormirá mais! Macbeth não dormirá mais!(Ato II,2).

Segundo movimento: Crime, o mal em ato

Intensifica-se o jogo com os punhais. Risco, velocidade e volúpia. O homem de La sinistra volta e senta-se na mesma cadeira, agora o trono. Está estático e a sua volta tudo se move. A cena, que no movimento anterior era só respiração, tensão e gesto, ganha voz (Ato II, 1 e 2 ) tecido sonoro que se instaura num andante e se intensifica num vivace embebido de raiva, desejo de cortar, penetrar, ver verter o sangue. No momento preciso de intensificação máxima, um ator degola o Rei. Súbito black-out. Trevas. Silêncio absoluto. Tudo fica impressionantemente imóvel. No escuro, ao microfone: Tu, terra sólida e firmemente assentada, não escutes os meus passos, nem para onde eles vão. Eu ameaço e ele dorme. Evocando os raios e trovões da rubrica inicial, luz estroboscópica e Territory, do Sepultura, desabam na cena com som e fúria. Duplas de mulher e homem cruzam a cena correndo, cada hora um sendo puxado pelo outro. Hipérbole da corrida, enquanto, em tempo lento e contínuo, outros atores colocam o trono sobre a mesa. Seu lugar agora é lugar desejado, o topo do mundo. Um ator tenta desesperadamente chegar a ele, enquanto os outros o impedem. Todos jogam com os textos/dispositivos pinçados do Ato II, 2 (cena da visão do punhal, da ação do punhal). Está feito. Silêncio. Tempo. Uma voz, a sábia voz da Natureza: Os cavalos de Duncan devoraram-se uns aos outros como se quisessem declarar guerra à raça humana.

\section{Terceiro movimento: Culpa}

Luz. Três atrizes. Olham suas próprias mãos, conferem as unhas. Cada uma delas saca um kit-manicure. Dispõem os utensílios sobre a mesa ou sobre o chão. Organizam os objetos com certa obsessão pela geometria dos objetos: alicates, lixas e esmaltes de vários matizes de vermelho. Atriz, lendo em voz alta: gula, deixa beijar, dona flor, inveja boa, pimenta, santo luxo, doce orgulho, possessão rosa, toque de 
ira, plano perfeito, esconde-esconde, pantera-negra, poção do amor, rebu, madona, Marilyn. Experimentam as cores. Nas unhas ou não. Não importa onde.

Entram outras três atrizes. Cada uma acende uma vela, de frente para a plateia, preparando com naturalidade o lugar onde vão realizar a emblemática cena de Lady Macbeth, a louca insone, tentando se livrar da "mancha maldita". O texto-ação das bruxas-manicures compõem e contrapõem com as Ladies-Lilith, formando duas pistas sonoras: esmalte vermelho e mancha maldita. Aqui ainda tem cheiro de sangue.

Assim que esta segunda "pista" de ação se estabelece, inicia-se uma terceira pista: homens que entram com baldes cheios de sangue. Instaura-se a terceira pista, aparecendo a primeira. Os homens dizem seu texto diretamente para um espectador, com o máximo de intensidade possível. Pessoa a pessoa. Durante o texto, mergulham e retiram as mãos no balde, mostrando-as ensanguentadas. A dor da culpa e da irreversibilidade de "o que está feito não pode ser desfeito" deve vazar-Ihes os olhos. Mas por que não pude pronunciar 'Amém'? O 'Amém' ficou parado na garganta.Uma vez que esta pista se instaura, desaparece a segunda pista (Ladies) enquanto brota a quarta e última pista: outros atores e atrizes, ocupando diferentes espaços, reagem a assassinos e carrascos invisíveis, com movimentos simples, diretos, simplesmente caindo no chão. Uma vez "mortos", podem levantar-se novamente, como se estudassem essa ação de morrer.

Corte Épico. Cessam as mortes, um único ator segue com a pista 3 (fragmentos Macbeth). Outro ator, no microfone, recorre novamente a Hamlet (este anti-Macbeth):

Não é monstruoso que esse ator aí, Por uma fábula, uma paixão fingida, Possa forçar a alma a sentir o que ele quer, De tal forma que seu rosto empalidece, Tem lágrimas nos olhos, angústia no semblante, A voz trêmula, e toda sua aparência Se ajusta ao que ele pretende? E tudo isso por nada!Por Macbeth! O que é Macbeth pra ele, ou ele pra Macbeth, Para que assim por ele se desespere? Que faria ele Se tivesse o papel e a deixa da paixão que eu tenho? Que EU TENHO!!!!!!

\section{Expiação}

Pausa. O espaço cênico está encharcado de sangue. Silêncio. Todos os corpos estão no chão, sem vida, exceto dois, um homem e uma mulher. Eles retomam a rotina do início do primeiro movimento (Mulher olha para homem/ homem olha para mulher), porém agora são eles próprios que narram suas ações, ora narrando primeiro e realizando a ação depois, como uma premonição, ora realizando a ação e narrando-a depois, como uma lembrança. Tempo cíclico, mas agora não é a voz-ex-machina 
do primeiro movimento, mas a voz do homem. Idade Média e Renascimento. Cristo, Zeus e Salve o Rei. Tudo com simplicidade, sem atuar. Saem de cena. Outro casal se levanta, e executam a mesma sequência de ações. Ao final de cada ação, experimentam o texto. Todos os homens são mortais/ Todos os homens são vaidosos/dizem que sangue pede sangue/ Já quase esqueci o gosto do medo.

Ouvimos novamente Quando corpus morietur, baixinho, enquanto um ator, sem atuar, com muita simplicidade, declama as famosas linhas do texto. Os atores que estavam sem vida, deitados sobre o chão ensanguentado se levantam, numa ação lenta e simples, durante o texto que segue no microfone:

\section{A vida não é mais que uma sombra errante, um mau ator que se pavoneia e se aflige no seu momento sobre o palco e então nada mais se ouve. É uma história contada por um idiota, cheia de som e fúria, significando nada.}

A música aumenta. O portão (as portas do inferno) se abre para o espaço exterior. Lá fora, um homem e uma mulher, ambos nus e cobertos de sangue e barro, estão em pé, expostos aos elementos. Um jato de água lava - e não há nenhum problema em quem segura a mangueira! - esse casal primordial, enquanto Quando Corpus Morietur ocupa todo o espaço sonoro e os demais atores apenas viram-se para a cena e a contemplam. Adão e Eva lavados, dupla primordial ao mesmo tempo expulsa e redimida, hierogamia entre Idade Média e Renascimento, entre Adão trágico e Lilith, Adão sacrificado e Eva pecadora. Amém, Evoé.

\section{Uma perspectiva mito-guiada e um teatro pré-apocalíptico}

Trabalhar sobre a peça maldita nesse ano de 2012 despertou meu imaginário para um Juízo Final. Assistindo aos alunos ensaiarem a cena do banquete, na qual o cadáver de Banqo senta-se à mesa, senti a urgência de um teatro que, mais do que fazer a crítica lúcida e ciente do contemporâneo (típico das atitudes "pós"), era urgente arriscar um "pré" que ao menos me consolasse com um horizonte de utopia. Perto do fim, dou a volta à cauda e, uroboricamente retorno ao mito e guiada, inspirada e apaixonada por ele, estabeleço cinco pontos - pois cinco é o número do homem divinizado - do meu teatro pré-apocalíptico.

Primeiro, é preciso desacelerar o tempo, para que seja possível pensar, contemplar, sentir e, principalmente, estar de verdade nos lugares, sem ser desviado pela expectativa do porvir, do momento que ainda não é presente. Chega de velozes e furiosos! Quando desaceleramos o tempo, vislumbramos o segundo ponto: o reen- 
cantamento do mundo, pois como diz Hilda Hilst, "se a gente olha tudo de um jeito vagaroso, tudo é sagrado." A velocidade nos impede de ver a alma do mundo (um mundo reencantado) e sem vê-la, o criar fica sem vida. Reencantar não é encher o mundo de fadas e duendes e sim aceitar que a diferença se manifeste. Apaixonar-se pela diferença seria então o terceiro ponto. Como Leda e o cisne. É a diferença que nos completa - no teatro e na vida. Um teatro apoiado nesses três pontos não tem lugar no atual sistema do mega-mundo-bobalizado, pois o próprio pensamento mítico está sufocado nele. Por isso, um teatro pré-apocalíptico deseja o menor: a sala de aula, os pequenos espaços de dimensões humanas, os processos colaborativos, as boas companhias. Um teatro do espectador, do cúmplice, não do anonimato do "público". Este é o quarto ponto: um teatro que acredita na potência do pequeno gesto. Por último, e concluindo com o quinto ponto, um teatro pré-apocalíptico é um teatro do corpo ao vivo, em carne e osso, pois o teatro é sedução e enamoramento e só se realiza no encontro. É preciso não ter medo de mostrar o osso e arriscar-se a perder a carne (ARTAUD, 1999). 
Imagens de Macabeth por Verônica Fabrini
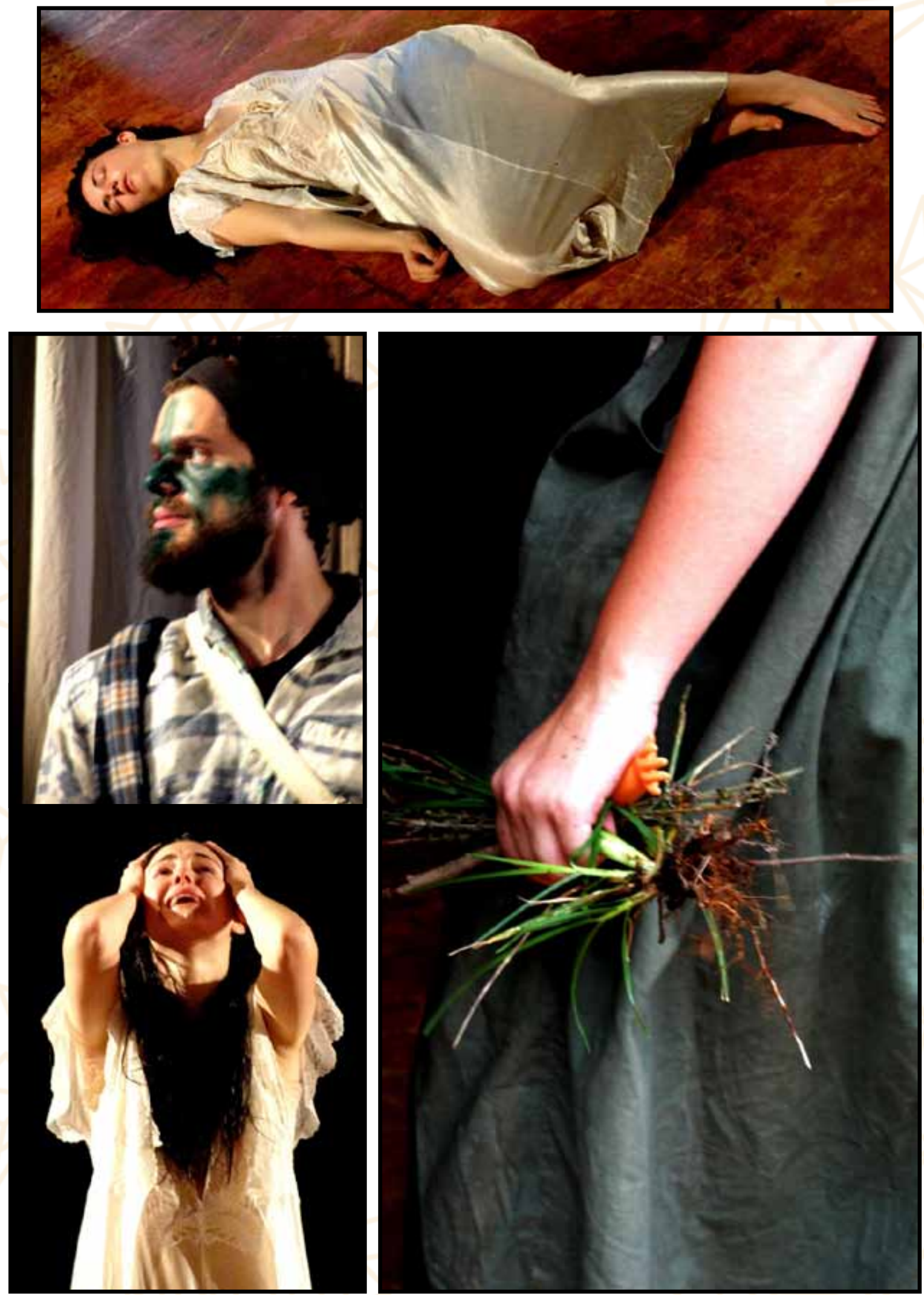


\section{Referências bibliográficas}

\section{Artigos}

FERÁL, Josette. Performance and Theatricality: The Subject Demystified. Modern Drama. New York, v. 25, n. 1, p. 170-181. mar. 1982.

Theatricality: The Specifity of Theatrical Language. SubStance, Vol. 31, Edição 98/99.

MELLO, Gláucia Boratto, Contribuições para o estudo do imaginário: Em Aberto, Brasília, ano 14, n.61, jan./mar. 1994.

SCHEFFLER, Ismael. A hermenêutica simbólica como possibilidade epistemológica para o estudo do espaço teatral. Periscope Magazine, $n^{\circ}$ 4, ano 2, dezembro de 2002

\section{Livros}

ARTAUD, Antonin. O teatro e seu duplo. São Paulo: Martins Fontes, 1999.

DURAND, Gilbert, O imaginário, Difel, 2009.

ELIADE, Mircea. O sagrado e o profano. São Paulo: Martins Fontes, 1991.

HUGHES, Ted, Shakespeare and the Goddess of Complete Being, Farrar, Straus \& Giroux, London, 1993.

SALOME, Lou Andreas, O erotismo, Editora Princípio, São Paulo, 1991.

YATES, Francis, The theatre of the world, Routdledge and Kegan Paul, London, 1978.

\section{Referencias para Macbeth / lado B: Quem é esse homem ensanguentado?}

\section{Textos}

Shakespeare, W.:Macbeth, Arden Edition, Routledge, London, 1987.

Shakespeare, W.: Hamlet, Arden Edition, Routledge, London, 1987.

(e várias traduções para o português de ambas as peças)

\section{Músicas}

Pergolesi, Stabat Mater XII:Quando corpus morietur, 1736.

http://www.youtube.com/watch?v=salW7UKruFO

Sepultura, Territory, em Chaos A.D.,1993 - http://letras.mus.br/sepultura/81197/traducao.html 